\title{
Kinetics of urease mediated calcite precipitation and permeability reduction of porous media evidenced by magnetic resonance imaging
}

\author{
S. Handley-Sidhu $\cdot$ E. Sham • M. O. Cuthbert • \\ S. Nougarol • M. Mantle • M. L. Johns • \\ L. E. Macaskie • J. C. Renshaw
}

Received: 7 October 2011 / Revised: 3 May 2012/ Accepted: 8 August 2012 / Published online: 29 March 2013

(C) Islamic Azad University (IAU) 2013

\begin{abstract}
The enzyme urease drives the hydrolysis of urea leading to the release of ammonium ions and bicarbonate; in the presence of calcium, the rise in $\mathrm{pH}$ leads to increased calcium carbonate saturation and the subsequent precipitation of calcite. Although such alkalinizing ureolysis is widespread in nature, most studies have focussed on bacteria (i.e. indigenous communities or urease-active Sporosarcina pasteurii) for calcite precipitation technologies. In this study, urease-active jack bean meal (from the legume Canavalia ensiformis) was used to drive calcite precipitation. The rates of ureolysis $\left(k_{\text {urea }}\right)$, determined from measured $\mathrm{NH}_{4}{ }^{+}$, enabled a direct comparison to microbial ureolysis rates reported in literature. It is also demonstrated that a simple single reaction model approach can simulate calcite precipitation very effectively (3-6\%
\end{abstract}

S. Handley-Sidhu $(\bowtie) \cdot$ M. O. Cuthbert · J. C. Renshaw School of Geography, Earth and Environmental Sciences, B15 2TT, Edgbaston, Birmingham, UK

e-mail: s.handley-sidhu@bham.ac.uk

E. Sham - M. Mantle

Department of Chemical Engineering and Biotechnology, University of Cambridge, Pembroke Street,

CB2 3RA Cambridge, UK

S. Nougarol

Ecole Nationale du Génie de l'Eau et de l'Environnement de Strasbourg, 67070 Strasbourg, France

M. L. Johns

University of Western Australia, School of Mechanical and Chemical Engineering, 35 Stirling Highway, Crawley, WA 6009, Australia

L. E. Macaskie

School of Biosciences University of Birmingham, B15 2TT, Edgbaston, Birmingham, UK normalised root-mean-square deviation). To investigate the reduction of permeability in porous media, jack bean meal $\left(0.5 \mathrm{~g} \mathrm{~L}^{-1}\right)$ and solutions $\left(400 \mathrm{mM}\right.$ urea and $\left.\mathrm{CaCl}_{2}\right)$ were simultaneously pumped into a borosilicate bead column. One-dimensional magnetic resonance profiling techniques were used, non-invasively, for the first time to quantify the porosity changes following calcite precipitation. In addition, two-dimensional slice selective magnetic resonance images (resolution of $\sim 0.5 \times 1.0 \mathrm{~mm}$ ) revealed that the exact location of calcite deposition was within the first $10 \mathrm{~mm}$ of the column. Column sacrifice and acid digestion also confirmed that $91.5 \%$ of calcite was located within the first $14 \mathrm{~mm}$ of the column. These results have important implications for the design of future calcite precipitation technologies and present a possible alternative to the well known bacterial approaches.

Keywords Urease $\cdot \mathrm{CaCO}_{3} \cdot$ Jack bean meal $\cdot$ Canavalia ensiformis · Ureolysis

\section{Introduction}

Calcite precipitation technologies (CPT) have a wide range of current and potential applications, including solid-phase capture and remediation of problematic trace metals and radionuclides (Curti 1999; Warren et al. 2001; Fujita et al. 2004; 2010), remediation of cracked concrete (Whiffin et al. 2007; De Muynck et al. 2008; Ghosh et al. 2009), durability of concrete structures (Ramachandran et al. 2001; De Muynck et al. 2010; Achal et al. 2011), treatment of urea from wastewaters (Hammes et al. 2003), carbon sequestration (White et al. 2003; Druckenmiller et al. 2006; Cunningham et al. 2009; Mitchell et al. 2010), soil improvement (Whiffin 2004) and sealing porosity or rock 
fractures (Ferris et al. 1996; Cunningham et al. 2009; Cuthbert et al. 2012; Tobler et al. 2012).

Biological CPT can be carried out by ureolysis using extracted urease enzymes or urease producing microorganisms. During ureolysis, the urease enzyme hydrolyses urea forming bicarbonate and ammonia (Eq. 1). The further hydrolysis of ammonia to ammonium (Eq. 2) leads to an increase in $\mathrm{pH}$ and a shift in the bicarbonate equilibrium (Eq. 3), subsequently leading to the precipitation of calcium and carbonate as calcite (Eq. 4) (Cunningham et al. 2009).

$$
\begin{aligned}
& \mathrm{NH}_{2} \mathrm{CONH}_{2}+2 \mathrm{H}_{2} \mathrm{O} \rightarrow 2 \mathrm{NH}_{3}+\mathrm{HCO}_{3}^{-}+\mathrm{H}^{+} \\
& 2 \mathrm{NH}_{3}+2 \mathrm{H}_{2} \mathrm{O} \leftrightarrow 2 \mathrm{NH}_{4}^{+}+2 \mathrm{OH}^{+} \\
& \mathrm{HCO}_{3}^{-}+\mathrm{H}^{+}+2 \mathrm{OH}^{-} \leftrightarrow \mathrm{CO}_{3}^{2-}+2 \mathrm{H}_{2} \mathrm{O} \\
& \mathrm{Ca}^{2+}+\mathrm{CO}_{3}^{2-} \leftrightarrow \mathrm{CaCO}_{3}
\end{aligned}
$$

Using a first-order kinetic law, Ferris et al. (2004) showed that the ureolysis rate constant can be calculated from experimental measurements of $\mathrm{NH}_{4}{ }^{+}$(Eq. 5), where $\left[\mathrm{NH}_{4}{ }^{+}\right]_{\mathrm{t}}$ is $\mathrm{NH}_{4}{ }^{+}$concentration produced over time, [urea $]_{0}$ is the initial urea concentration and $k_{\text {urea }}$ is the ureolysis rate constant $\left(\right.$ day $\left.^{-1}\right)$ :

$$
\left[\mathrm{NH}_{4}^{+}\right]_{t}=2[\text { urea }]_{0}\left(1-e^{-k_{\text {urea }} t}\right)
$$

Although factors such as temperature, $\mathrm{pH}$ and substrate concentration are known to influence the activity of urease (Krajewska 2009a, b), this first-order kinetic rate $\left(k_{\text {urea }}\right)$ has been successfully applied to a range of experimental microbial ureolysis data (Table 1). For microbial ureolysis, the $k_{\text {urea }}$ has been shown to increase with increasing biomass concentrations [measured by optical density (OD)] of Sporosarcina pasteurii (previously known as Bacillus pasteurii) (Tobler et al. 2011). Temperature is also known to affect ureolysis rates for $S$. pasteurii, with $k_{\text {urea }}$ increasing from 0.09 at $10{ }^{\circ} \mathrm{C}$ to 0.91 at $20{ }^{\circ} \mathrm{C}$ (Ferris et al. 2004). Research by Tobler et al. (2011) also found that the ureolytic activity of an uncharacterised indigenous microbial consortium (from Birmingham, UK groundwater) was much lower than $S$. pasteurii, for the same biomass concentrations (as determined by OD), with $k_{\text {urea }}=0.04$ for the indigenous community compared to 0.13 for $S$. pasteurii.

The urease enzyme is widespread in nature and is found in plants, bacteria, fungi, mammals and soils. Although the structure differs slightly, its function remains the same (Krajewska 2009a). The specific activity of an enzyme can be calculated but depends on the purity of the enzyme and experimental conditions (i.e. $\mathrm{pH}$, temperature and substrate concentrations). The activity of purified urease enzyme from Canavalia ensiformis (Jack Bean) is reported as 2,700-3,500 units
( $\mu$ mol urea hydrolysed/min per $\mathrm{mg}$ of protein), with an optimal pH of 7.0-7.5 (Krajewska 2009a). The activity of urease enzyme from $S$. pasteurii is similar to the value of jack bean urease at 2,500 units, with an optimal pH of 8.0 (Krajewska 2009a).

There are challenges to the successful development and optimisation of CPT for sealing porosity or rock fractures. For example, using an indigenous bacterial community for CPT requires enriching the biomass by adding organic nutrients such as molasses (Tobler et al. 2011). Depending on the nutrient added, environmental problems such as eutrophication or pollution of groundwater may occur. When injecting ureolytic bacteria (i.e. $S$. pasteurii) adding nutrients will not be necessary (Tobler et al. 2011). However, research by Cuthbert et al. (2012) has found that ureolysis is limited by the eventual encapsulation of ureolytic bacteria and biofilm by calcite. This would mean that for sealing large voids (i.e. porous media or rock fractures) additional injections of ureolytic bacteria would be required. Bioclogging is an issue for CPT because it causes problems for further injections of the cementing substrates and because blocking by organic material is not stable as it will degrade over time. Research by Nemati et al. (2005) found that the plugging of porous media by biomass was a factor when using ureolytic bacteria.

Urease-active jack bean meal (JBM) is a non-hazardous, general laboratory chemical containing unpurified urease enzyme, using JBM could reduce some of the problems associated with microbial CPT (i.e. bioclogging, nutrient pollution) and reduce costs (i.e. biotechnology, nutrient costs). Research has also shown that a purified urease enzyme can tolerate higher urea and calcium concentrations than ureolytic bacteria; therefore, potentially higher volumes of calcite can be produced (Nemati and Voordouw 2003; Nemati et al. 2005). The objectives of this work are: (1) to validate the use of urease-active JBM for CPT and to compare the rate of ureolysis $\left(k_{\text {urea }}\right)$ against bacterial CPT rates reported in the literature and (2) to determine the efficiency of urease-active JBM to reduce the porosity and permeability of porous material measured by magnetic resonance imaging (MRI). This research was conducted at the University of Birmingham and the University of Cambridge, from April 2010 to February 2011.

\section{Materials and methods}

Batch urease-active jack bean meal experiments

The kinetics of calcite $\left(\mathrm{CaCO}_{3}\right)$ formation was investigated using different concentrations of urease-active 
Table 1 Experimental Jack bean meal and reported microbial ureolysis rates $\left(k_{\text {urea }}\right)$

\begin{tabular}{|c|c|c|c|c|c|c|}
\hline Sample & $\mathrm{OD}_{600 \mathrm{~nm}}$ & Urea $(\mathrm{mM})$ & $\mathrm{Ca}^{2+}(\mathrm{mM})$ & Temp $\left({ }^{\circ} \mathrm{C}\right)$ & $\mathrm{k}_{\text {urea }}\left(\mathrm{d}^{-1}\right)$ & Reference \\
\hline $\begin{array}{l}\text { NGW bacteria incubated in high nutrients } \\
\left(1.0 \mathrm{~g} \mathrm{~L}^{-1} \text { molasses }\right)\end{array}$ & 0.03 & 250 & 50 & 20 & 0.04 & (Tobler et al. 2011) \\
\hline AGW with $S$. pasteurii & 0.03 & 250 & 200 & 20 & 0.13 & (Tobler et al. 2011) \\
\hline AGW with $S$. pasteurii & 0.07 & 250 & 200 & 20 & 2.29 & (Tobler et al. 2011) \\
\hline AGW with $S$. pasteurii & 0.05 & $33-333$ & 20 & 30 & $0.996 \pm 0.016$ & (Dupraz et al. 2009) \\
\hline $\begin{array}{l}\text { NGW bacterial incubated in high nutrients } \\
\text { (molasses) }\end{array}$ & $\mathrm{n} / \mathrm{d}$ & 50 & $\mathrm{n} / \mathrm{d}$ & $\sim 12$ & $0.016-0.057$ & (Fujita et al. 2008) \\
\hline AGW with $S$. pasteurii & 0.07 & 6 & 0.63 & 10 & 0.09 & (Ferris et al. 2004) \\
\hline AGW with $S$. pasteurii & 0.07 & 6 & 0.63 & 15 & 0.18 & (Ferris et al. 2004) \\
\hline AGW with S. pasteurii & 0.07 & 6 & 0.63 & 20 & 0.91 & (Ferris et al. 2004) \\
\hline Jack bean meal $\left(0.5 \mathrm{~g} \mathrm{~L}^{-1}\right)$ & - & 200 & 400 & 10 & 0.27 & This study \\
\hline Jack bean meal $\left(0.25 \mathrm{~g} \mathrm{~L}^{-1}\right)$ & - & 200 & 400 & 10 & 0.15 & This study \\
\hline Jack bean meal $\left(0.125 \mathrm{~g} \mathrm{~L}^{-1}\right)$ & - & 200 & 400 & 10 & 0.05 & This study \\
\hline
\end{tabular}

$n / d$ no data, $A G W$ artificial groundwater, $N G W$ natural groundwater

JBM. A solution of $400 \mathrm{mM} \mathrm{Ca}{ }^{2+}$ and $200 \mathrm{mM}$ urea was prepared from $\mathrm{CaCl}_{2} \cdot 2 \mathrm{H}_{2} \mathrm{O}$ (ACS reagent, SigmaAldrich), urea salts (AnalaR, BDH) and high purity water (MQ water $\geq 18 \mathrm{M} \Omega \mathrm{cm}^{-1}$ ). A known weight of JBM (Fisher Scientific) was added to triplicate flasks containing $250 \mathrm{~mL}$ of solution $\left(400 \mathrm{mM} \mathrm{Ca}{ }^{2+} ; 200 \mathrm{mM}\right.$ urea) to give final concentrations of $0,0.125,0.25$ and $0.5 \mathrm{~g} \mathrm{~L}^{-1}$. The flasks were stored in the dark on an orbital shaker $(100 \mathrm{rpm})$ at $10^{\circ} \mathrm{C}$. At known time points $(0-335 \mathrm{~h})$, the flasks contents were analysed for changes in solution chemistry. The $\mathrm{pH}$ of the solution was measured (VWR; 662-1,759 probe) and a subsample of solution $(1 \mathrm{~mL})$ was filtered $(50 \mathrm{kDa}$, Millipore, $20 \mathrm{~min}$, $4,500 \mathrm{~g})$ to remove the active urease enzyme $(\sim 545 \mathrm{kDa}$ in size) and analysed for $\mathrm{Ca}^{2+}$ and $\mathrm{NH}_{4}{ }^{+}$using cation chromatography (Dionex; ICS-1100).

\section{Jack bean meal characterisation}

The elemental composition of the JBM was determined (wt \% of each element) using X-ray fluorescence (XRF; Bruker S8). An accurately weighed mass (0.2 g) of powdered sample was prepared in a pellet using Hoechst wax and analysed using an $\mathrm{Rh} \mathrm{X}$-ray source in a helium atmosphere. The protein content of JBM dissolved in MQ water was determined using the $\mathrm{Bi}$ cinchoninic Acid Kit assay for proteins at absorbance maximum $562 \mathrm{~nm}$ according to the manufacturer's instructions. The loss-on-ignition (LOI) method was used to determine organic matter content. A portion of accurately weighed JBM $(\sim 1 \mathrm{~g})$ was placed in a ceramic boat and heated to $450{ }^{\circ} \mathrm{C}$ for $4 \mathrm{~h}$. The material was allowed to cool in a desiccator and reweighed to determine $\%$ organic matter.

Jack bean meal urease activity

The activity ( $\mu \mathrm{mol}$ of urea/min per $\mathrm{mg}$ of protein) of the dissolved urease released from JBM was assayed. Quadruplicate solutions containing $200 \mathrm{mM}$ urea at $\mathrm{pH} 7$ (phosphate saline bioreagent buffer, Sigma-Aldrich) were reacted with $5 \mathrm{~g} \mathrm{~L}^{-1} \mathrm{JBM}$ at room temperature. At the set time point of $5 \mathrm{~min}$, the solutions were filtered $(50 \mathrm{kDa}$; Millipore) to remove the active urease and the liberated $\mathrm{NH}_{4}{ }^{+}$was analysed by cation chromatography (Dionex, ICS-1100).

Blocking of porous material by urease-active JBM

Investigations into the blocking of porous media were conducted at room temperature using a column (perspex; $69 \times 37 \mathrm{~mm}$ i.d) containing borosilicate beads $(100 \mu \mathrm{m}$; Ballotini $\left.{ }^{\circledR}\right)$. The column was fully packed $\left(74.2 \mathrm{~cm}^{3}\right)$ with borosilicate beads and deionised water using a tapping motion to dislodge air bubbles; the packing porosity was determined gravimetrically to be 0.385 . Etched caps were used to aid fluid distribution within the column and covered with a nylon mesh to contain the beads and allow the solutions to flow freely. Two solutions, JBM solution $\left(0.5 \mathrm{~g} \mathrm{~L}^{-1}\right)$ and cementing solution 
(400 mM urea; $400 \mathrm{mM} \mathrm{Ca}^{2+}$ ), were prepared in deionised water. The two solutions were pumped at a constant flow rate using a dual syringe pump (30 $\pm 0.3 \mathrm{~mL} \mathrm{~h}^{-1}$; ISCO Model 260D) and mixed prior to the column inlet using an araldite nozzle. After mixing, the final concentration of solution pumped through the column was $200 \mathrm{mM} \mathrm{Ca}{ }^{2+}, 200 \mathrm{mM}$ urea and $0.25 \mathrm{~g} \mathrm{~L}^{-1} \mathrm{JBM}$. The column was run for $65 \mathrm{~h}$ and changes in the head gradient across the column were measured over time. Changes in the permeability of the porous media were calculated using the Darcy's equation.

Magnetic resonance imaging techniques

Magnetic resonance imaging (MRI) has recently been used to determine changes in hydrodynamic dispersion in porous media by biologically mediated precipitation (Fridjonsson et al. 2011). MRI measurements were performed on a horizontal-bore magnet (Bruker; AV 85) with a magnetic field strength of $2 \mathrm{~T}$ and a birdcage radiofrequency coil with a diameter of $60 \mathrm{~mm}$. For hydrogen nuclei $\left({ }^{1} \mathrm{H}\right)$, the resonant frequency is 85.18 MHz. A standard 1D spin echo profiling pulse sequence and 2D spin echo imaging pulse sequence (Callaghan 1993) were used for the acquisitions. 1D profiles were acquired over two scans along the length of the sample in the $z$-(axial) direction with 128 pixels for a field of view of $120 \mathrm{~mm}$, giving a spatial resolution of $934 \mu \mathrm{m}$. The echo time (TE) was $4.34 \mathrm{~ms}$ and the repetition time $(T R)$ was $30 \mathrm{~s}$. The $2 \mathrm{D}$ images were acquired over four scans in the $x-z$ plane with $256 \times 128$ pixels for a field of view of $120 \mathrm{~mm}$ in both directions. The slice thickness used was $5 \mathrm{~mm}$. The echo time (TE) was $2.49 \mathrm{~ms}$ and the repetition time (TR) was $15 \mathrm{~s}$. Spin-lattice $\left(T_{1}\right)$ relaxation losses were corrected for through the sufficiently long repetition times. Spinspin $\left(T_{2}\right)$ relaxation losses were determined to be negligible at less than $2 \%$.

To fully quantify the nuclear magnetic resonance imaging (NMRI) signal intensity, a calibration phantom was constructed by mixing deionised water with heavy water $\left(\mathrm{D}_{2} \mathrm{O}\right.$, Aldrich $\left.99 \%\right)$ such that the volumetric water fraction was 0.3 (Stevenson et al. 2007). This was then used to calculate a calibration factor so that the raw magnetic resonance data could be expressed as a volumetric liquid fraction. Corresponding 1D profile and 2D images, as described before, were acquired for the phantom and hence corrected. Porosity profiles and images, as described before, were obtained by dividing the profiles and images by that of the suitably corrected calibration phantom.
Precipitate characterisation

A sample of precipitate was recovered from the batch flasks and analysed by X-ray powder diffraction (XRD; Bruker D8 Advanced X-ray diffractometer; $10^{\circ}-60^{\circ}$; $20 \mathrm{~min}$; step $0.02 \theta$; count time $0.48 \mathrm{~s}$; $\mathrm{Cu} \mathrm{Ka}$ radiation). After $65 \mathrm{~h}$, the column was sacrificed and the content was separated into 14 similar length sections. A small sample ( $\leq$ micro spatula) of column beads was mounted onto stubs, gold-coated and imaged using an environmental scanning electron microscope (ESEM) with energy dispersive X-ray (EDX) under high vacuum mode (FEI Philips FEG ESEM XL30; Detector $15 \mathrm{kV}$ ). The remaining portions were digested with $2 \mathrm{M} \mathrm{HCl}$ and the dissolved $\mathrm{Ca}^{2+}$ was analysed by cation chromatography. The measured calcium content $(\mathrm{mg})$ was multiplied by the ratio $2.5\left(\mathrm{CaCO}_{3} \mathrm{mw} 100.09 / \mathrm{Ca} \mathrm{mw} 40.08\right)$ to determine the mass of $\mathrm{CaCO}_{3}(\mathrm{mg})$ in each segment of the column (Table 2).

\section{Results and discussion}

Urease-active jack bean meal batch experiments

The changes in batch solution concentrations of $\mathrm{Ca}^{2+}$ and $\mathrm{NH}_{4}{ }^{+}$for experiments using urease-active JBM

Table 2 The amount of calcite formed in porous flow column as determined by calcium analysis after acid digestion

\begin{tabular}{llcc}
\hline Column & $\begin{array}{l}\text { Segment Length } \\
(\mathrm{mm})\end{array}$ & $\begin{array}{c}\mathrm{CaCO}_{3} \\
(\mathrm{mg})\end{array}$ & $\begin{array}{l}\text { \% of total } \\
\mathrm{CaCO}_{3}\end{array}$ \\
\hline Inlet filter & 0 & 18.7 & 2.6 \\
Inlet & $0-5.1$ & 417.8 & 57.3 \\
1 & $5.1-9.1$ & 153.0 & 21.0 \\
2 & $9.1-13.6$ & 77.2 & 10.6 \\
3 & $13.6-18.3$ & 19.6 & 2.7 \\
4 & $18.3-23.6$ & 11.5 & 1.6 \\
5 & $23.6-28.9$ & 4.5 & 0.6 \\
6 & $28.9-32.8$ & 4.1 & 0.6 \\
7 & $32.8-37.7$ & 4.0 & 0.5 \\
8 & $37.7-41.1$ & 2.4 & 0.3 \\
9 & $41.1-46.5$ & 3.6 & 0.5 \\
10 & $46.5-50.6$ & 2.5 & 0.3 \\
11 & $50.6-57.0$ & 3.4 & 0.5 \\
12 & $57.0-63.0$ & 2.4 & 0.3 \\
Outlet & $63.0-69.0$ & 2.8 & 0.4 \\
Outlet & 69.0 & 1.7 & 0.2 \\
filter & & & \\
\hline
\end{tabular}



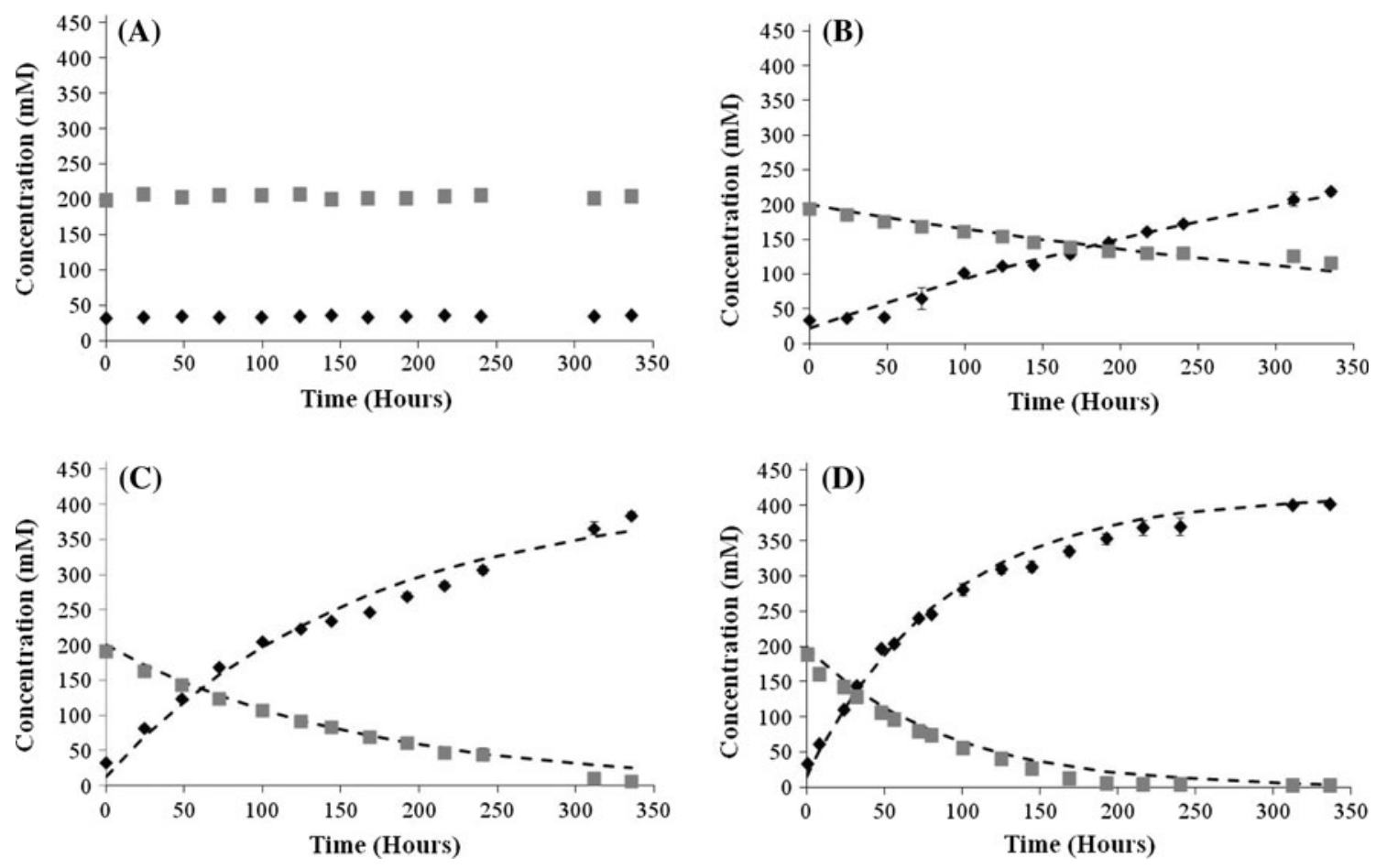

Fig. 1 Time series showing changes in solution $\mathrm{Ca}^{2+}$ (square) and $\mathrm{NH}_{4}{ }^{+}$(diamond) for urease-active JBM concentrations of $0(\mathbf{a}), 0.125$ (b), 0.25 (c) and $0.5 \mathrm{~g} \mathrm{~L}^{-1}$ (d). Model fits (dashed line) are shown on

graphs a-c. Error bars are \pm 1 standard deviation $(n=3)$, where not shown these were within the dimension of the symbols

concentrations of $0,0.125,0.25$ and $0.5 \mathrm{~g} \mathrm{~L}^{-1}$ are shown in Fig. 1. At $0 \mathrm{~g} \mathrm{~L}^{-1}$, there were no significant changes in solution chemistry and no calcite was formed (Fig. 1a). In the flasks containing $0.125 \mathrm{~g} \mathrm{~L}^{-1}$ and $0.25 \mathrm{~g} \mathrm{~L}^{-1} \mathrm{JBM}$, the $\mathrm{Ca}^{2+}$ concentration in solution decreased from $200 \mathrm{mM}$ to $106.67 \mathrm{mM}$ and $<7 \mathrm{mM}$ after $335 \mathrm{~h}$, respectively (Fig. $1 \mathrm{~b}, \mathrm{c}$ ). In the $0.5 \mathrm{~g} \mathrm{~L}^{-1} \mathrm{JBM}$ flask, the decrease in $\mathrm{Ca}^{2+}$ was more rapid, to $<5 \mathrm{mM}$ after $192 \mathrm{~h}$ (Fig. 1d).

Since some background $\mathrm{NH}_{4}{ }^{+}$was present at the start of the experiments, Eq. 5 was modified as follows:

$\left[\mathrm{NH}_{4}^{+}\right]_{t}=\left[\mathrm{NH}_{4}^{+}\right]_{0}+2[\text { urea }]_{0}\left(1-e^{-k_{\text {urea }} t}\right)$

where $\left[\mathrm{NH}_{4}^{+}\right]_{0}$ is the initial concentration of ammonium. Eq. 6 was then fitted to the experimental $\mathrm{NH}_{4}{ }^{+}$data giving values for $k_{\text {urea }}$ of $0.05,0.15$ and 0.27 day $^{-1}$, for the 0.125 , 0.25 and $0.5 \mathrm{~g} \mathrm{~L}^{-1} \mathrm{JBM}$ experiments, respectively (Fig. 1 $\mathrm{b}-\mathrm{d})$. Assuming that all the carbonate produced by ureolysis immediately precipitates to calcium carbonate, reactions $1-4$ can be summarised using the following single reaction:

$\mathrm{NH}_{2} \mathrm{CONH}_{2}+2 \mathrm{H}_{2} \mathrm{O}+\mathrm{CaCI}_{2} \stackrel{\text { urease }}{\rightarrow} 2 \mathrm{NH}_{4}^{+}+\mathrm{CaCO}_{3}(\mathrm{~s})+2 \mathrm{CI}^{-}$
Since, from Eq. 7, for every $2 \mathrm{M}$ of ammonium produced $1 \mathrm{M}$ of calcium ions should be removed, from Eq. 5, an expression for the amount of calcium remaining in solution can be derived, as follows:

$\left[\mathrm{Ca}^{2+}\right]_{t}=\left[\mathrm{Ca}^{2+}\right]_{0}-[\text { urea }]_{0}\left(1-\mathrm{e}^{-k_{\text {urea }} t}\right)$

This equation was fitted to the experimental data as shown in Fig. 1 b, d. Model fits were good (3-6\% normalised root-mean-square deviation) and the overall mass balances were within $<10 \%$. If $k_{\text {urea }}$ values are optimised against the ammonium data alone using Eq. 6 and then these are used to predict the calcium concentrations using Eq. 8, the resulting model fit to the observed calcium data is only slightly reduced with normalised root-mean-square deviations of $4-7 \%$. This confirms that the single reaction model may be adequate in such cases for simulating carbonate precipitation, as previously suggested by (Van Paassen 2009; Cuthbert et al. 2012).

The $\mathrm{pH}$ data obtained confirmed the process of ureolysis (Fig. 2a) (Stocks-Fischer et al. 1999; Achal and Pan 2011). Initially at $0.5 \mathrm{~h}$, the $\mathrm{pH}$ was above 8.5 for all of the JBM concentrations $(0.125,0.25$ and $0.5 \mathrm{~g}$ $\mathrm{L}^{-1}$ ). This can be explained as ureolysis leads to an 


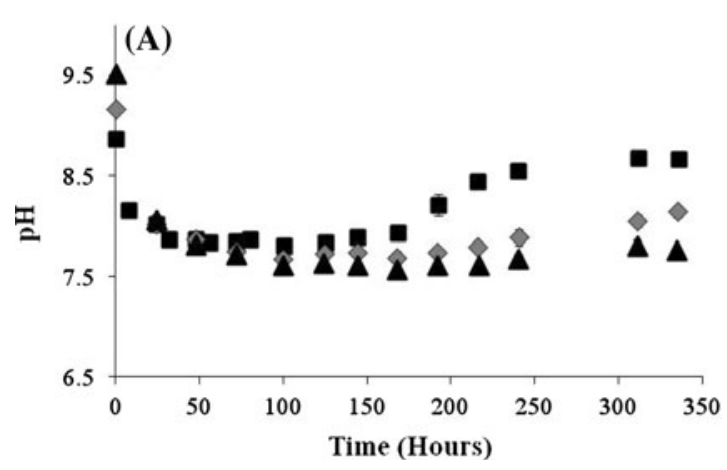

Fig. 2 Showing a the $\mathrm{pH}$ data for the 0.125 (triangle), 0.25 (diamond) and $0.5 \mathrm{~g} \mathrm{~L}^{-1}$ (square) urease-active JBM batch experiments. Also showing $\mathbf{b}$ the linear relationship between $k_{\text {urea }}$ and

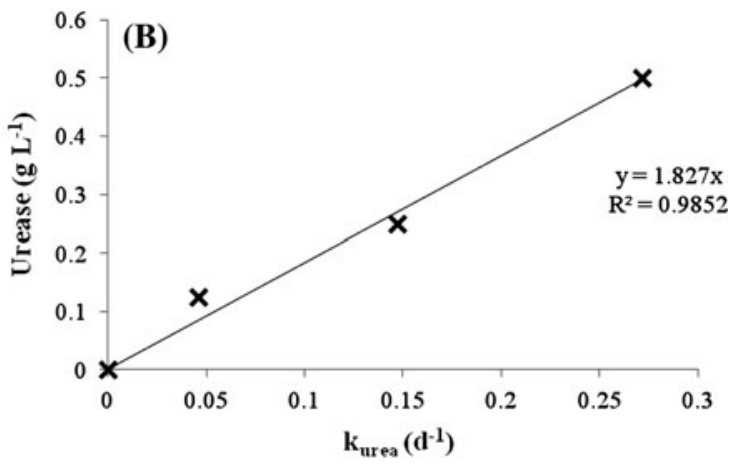

urease concentration $\left(\mathrm{g} \mathrm{L}^{-1}\right)$. Error bars are \pm 1 standard deviation $(n=3)$, where not shown these were within the dimension of the symbols
Fig. 3 Column dimensions and orientation a for JBM blocking experiments and 1D magnetic resonance profiles $\mathbf{b}$ depicting the porosity along the column at time zero (straight line) and after $65 \mathrm{~h}$ (dashed lines)
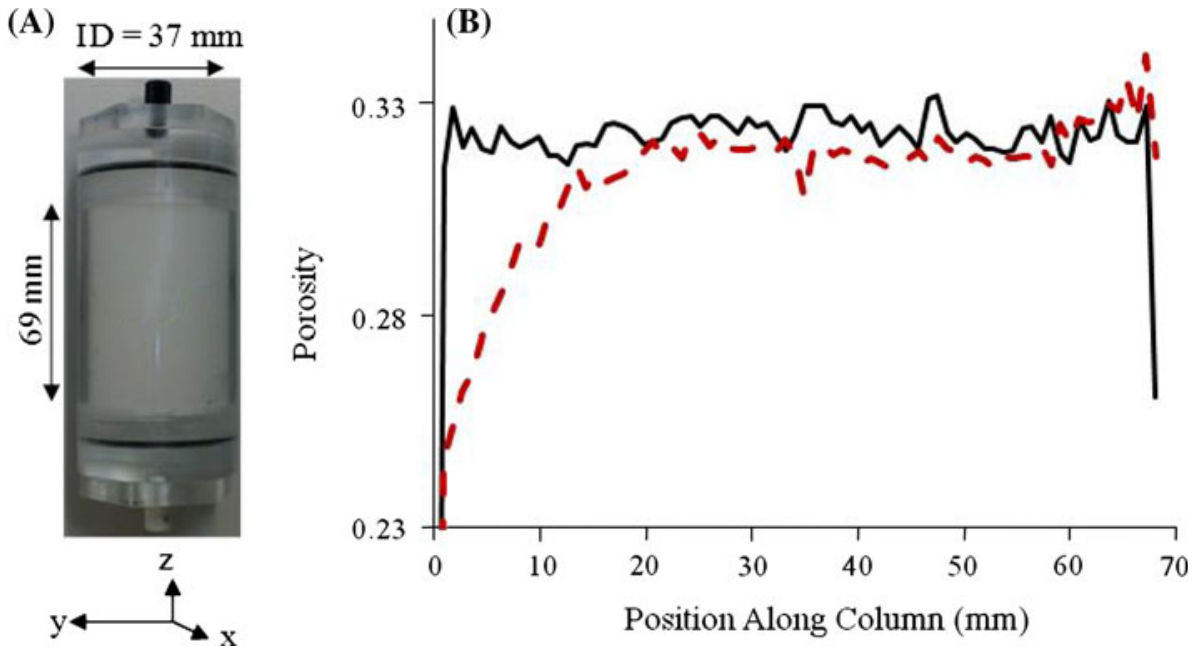

indigenous groundwater bacteria (0.03 OD) sampled from Birmingham, UK.

Jack bean meal characterisation

The JBM was characterised so that if applied to the environment for engineering CPT the groundwater quality can be maintained. The elemental composition of JBM showed that it contained various non-carbon elements $(4.12 \% \mathrm{~K}$, $0.83 \% \mathrm{P}, 0.51 \% \mathrm{~S}, 0.49 \% \mathrm{Ca})$, chloride $(>0.12 \%)$ and trace metals (Mg, Fe, $\mathrm{Si}, \mathrm{Zn}$ and $\mathrm{Cu}$ ). The JBM also contained a high organic matter content of $\sim 95 \%$ (this organic content may range from complex cellulose, to proteins and simple sugars) and a protein content of $8.44 \pm 0.2 \%$. The urease activity for JBM was calculated 
as only $3.13 \pm 0.16 \mu \mathrm{M}$ units. This value is much lower than purified JBM urease at 2,700-3,500 units; however, as jack beans only contain $0.07-0.14 \%$ urease/dry mass
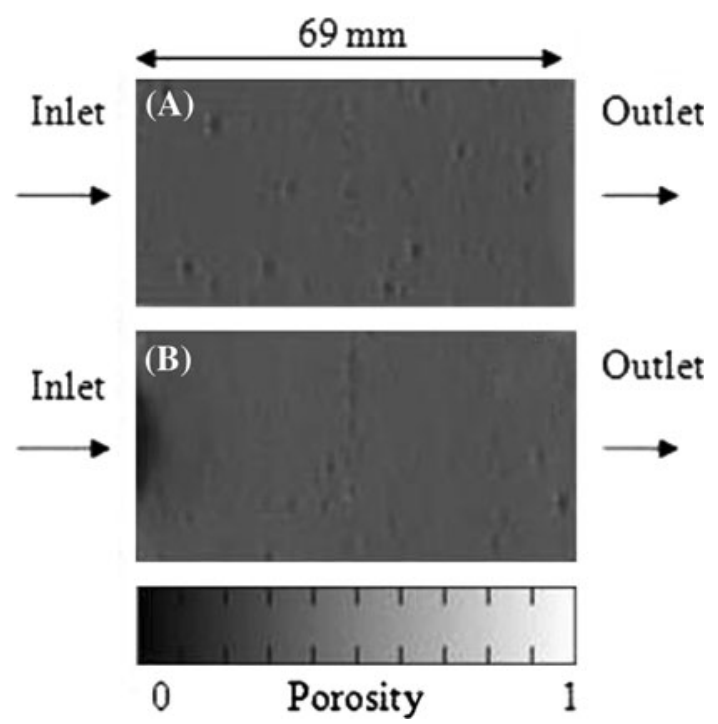

Outlet

Fig. 4 2D MRI depicting the porosity changes due to the formation of calcite precipitate along the central $x-z$ plane of the column, showing (a) at time zero and (b) after $65 \mathrm{~h}$
(Krajewska 2009a), this lower value obtained is within the expected range.

Blocking of porous media by calcite

1D and 2D MRI images were acquired to determine the formation of calcium calcite precipitate in situ. The average initial porosity along the length of the column was determined to be $0.323 \pm 5.76 \times 10^{-3}$ where the error is one standard deviation calculated from the signal area of the $\mathrm{D}_{2} \mathrm{O} / \mathrm{H}_{2} \mathrm{O}$ phantom (Fig. 3b). The $2 \mathrm{D} \mathrm{x}-\mathrm{z}$ porosity images were acquired from the centre of the column with a resolution of $467 \times 934 \mu \mathrm{m}$ (Fig. 4). This shows that the precipitate blocked the initial $10 \mathrm{~mm}$ of the column, reducing the local porosity in the inlet to $0.25 \pm 5.76 \times 10^{-3}$. In addition, after $64 \mathrm{~h}$ of treatment with cementing fluids $\left(\mathrm{Ca}^{2+}\right.$ and urea), the porosity across the remaining length $(69 \mathrm{~mm})$ of the column was $0.313 \pm 5.76 \times 10^{-3}$ and is approximately the same as the initial average porosity values. The pore space was determined gravimetrically to have decreased by $2.08 \%$, which is in reasonable agreement with the nuclear MRI measurements which yield a $3.16 \%$ reduction. However, despite this relatively modest reduction in overall porosity,
Fig. 5 SEM images showing calcite formed in the porous flow column. Showing a indented calcite from bead cementing (arrowed) b and c calcite formed on glass beads (circled) and $\mathbf{d}$ individual calcite crystal
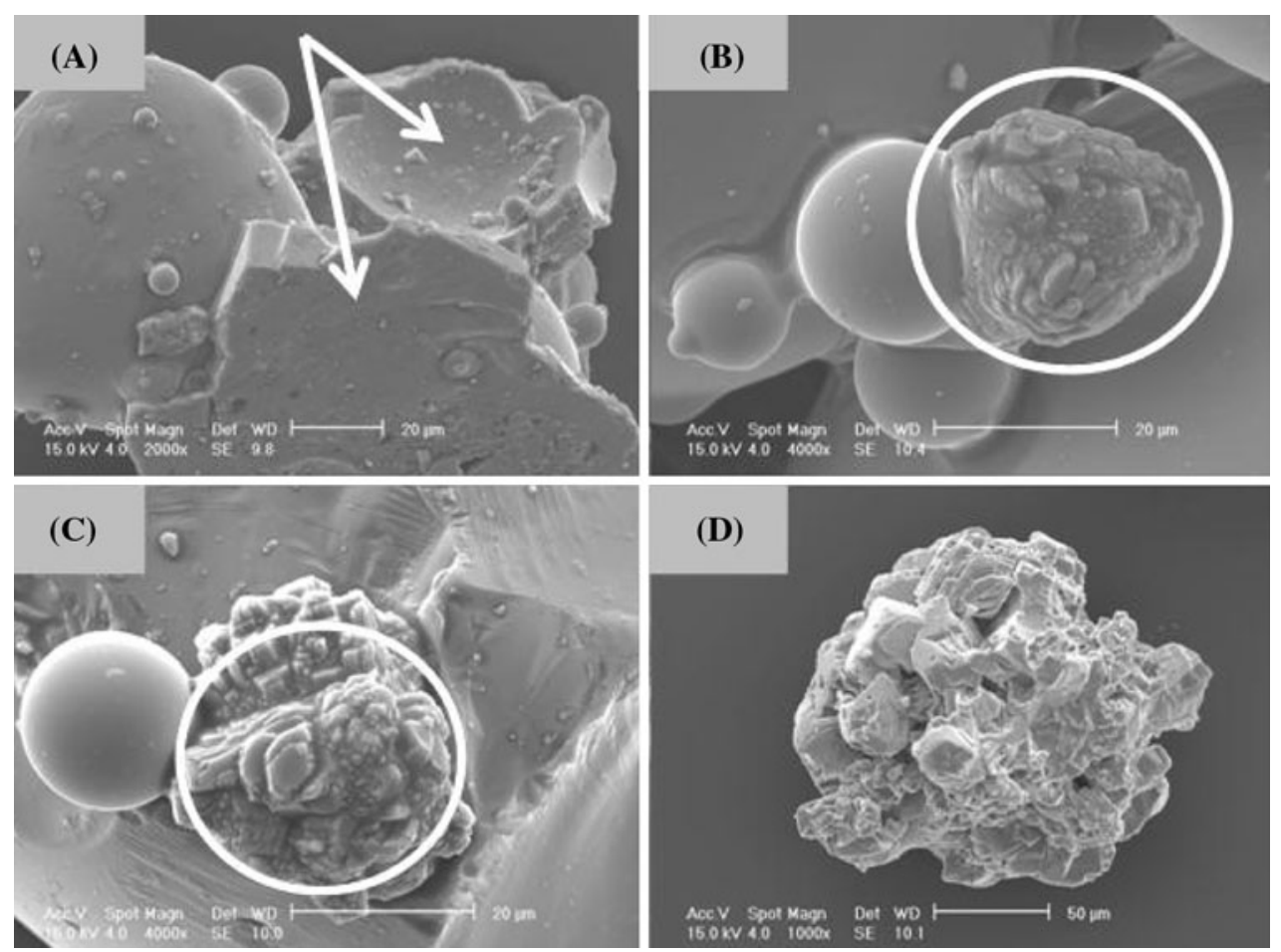
permeability was seen to reduce significantly from 9.99 to 0.175 Darcy.

Precipitate characterisation and column distribution

X-ray powder diffraction (XRD) patterns were obtained for precipitate from the batch experiments. The XRD pattern matched calcite (JCPDS database; Pattern number 01-071-3699). As reported by MRI data, examination of calcite distribution by digestion (Table 2) also confirmed that the majority of the calcite $(666.7 \mathrm{mg} ; 91.5 \%)$ was located within the first $0-14 \mathrm{~mm}$ of the column and only $42.9 \mathrm{mg}(8.5 \%)$ of the calcite was in the remaining column length $(14-69.0 \mathrm{~mm})$. The blocking of the first $14 \mathrm{~mm}$ of the column confirmed that calcite was nucleated at this initial location. This initial nucleated calcite probably acted as a site of additional crystal growth (Mitchell and Ferris 2006) and as a site for urease sorption and spatially focused hydrolysis. Urease sorption to minerals such as clays and calcium phosphates is well known, and this can be manipulated by changing the solution chemistry (Gianfreda et al. 1992; Marzadori et al. 1998). Blocking of the inlet was also observed by Tobler et al. (2012) when using parallel continuous injections of s. Pasteurii and cementing fluid. When a staged injection method was used (repeated injections of s. Pasteurii, followed by cementing fluid), a more homogenous distribution of calcite precipitation was observed within the column and a greater porosity reduction (Tobler et al. 2012). The SEM images from a flow column (Fig. 5a) show a glass bead and calcite precipitation as confirmed by EDX analysis, the crater indentations (arrowed) show calcite compaction formed around borosilicate beads. Calcite formation was also observed on the surfaces of borosilicate beads (Fig. 5 b, c) and as individual calcite crystals (Fig. 5d).

\section{Conclusion}

The calculated $k_{\text {urea }}$ of urease JBM enables a direct comparison with microbial calcite precipitation rates reported in the literature and the modelling of JBM demonstrates that a single reaction works well for the conditions studied, thus reducing the need for complex saturation dependent or nucleation models. MR imaging was successfully applied to image the blocking of porous material using JBM with a spatial resolution of $\sim 0.5 \times 1.0 \mathrm{~mm}$. This offers an attractive non-invasive technique to quantify the spatial distribution of calcite precipitation in a range of porous media. The possibility of using NMR logging tools to quantify calcite precipitation in real geological formations will be explored in future. Research presented here shows that at reasonable flow rates of $30 \mathrm{~mL} \mathrm{~h}^{-1}$ the majority of the calcite precipitation $(91.5 \%)$ occurred at the initial column section $0-14 \mathrm{~mm}$. This was most likely due to the initial nucleated calcite acting as a site of additional crystal growth and as a site for urease sorption and spatially focused hydrolysis. Blocking the initial section of a fracture or porous media would be undesirable for some engineering applications such as sealing porosity or rock fractures; however, it might be appropriate for the durability of concrete structures and soil improvement. A more homogenous distribution of calcite blocking may be obtained by adjusting the solution chemistry or by used staged injections. These results have important implications for future engineering designs and with controlled absorption, this urease-active JBM, depending on the application, could be a good alternative to the more well known bacterial approaches.

Acknowledgments Financial support was provided by EPSRC (EP/ G063699/1). The XRF and XRD used in this research were obtained, through Birmingham Science City: Creating and Characterising Next Generation Advanced Materials (West Midlands Centre for Advanced Materials Project 1), with support from Advantage West Midlands (AWM) and part funded by the European Regional Development Fund (ERDF).

\section{References}

Achal V, Pan X (2011) Characterization of urease and carbonic anhydrase producing bacteria and their role in calcite precipitation. Current Microbiol 62:894-902. doi:10.1007/s00284-0109801-4

Achal V, Pan X, Ozyurt N (2011) Improved strength and durability of fly ash-amended concrete by microbial calcite precipitation. Ecol Eng 37:554-559. http://dx.doi.org/10.1016/j.ecoleng.2010.11. 009

Callaghan PT (1993) Principles of nuclear magnetic resonance microscopy. Oxford University Press, Oxford

Cunningham AB, Gerlach R, Spangler L, Mitchell AC (2009). Microbially enhanced geologic containment of sequestered supercritical $\mathrm{CO}_{2}$. Energy Procedia. 1:3245-3252. http://dx.doi. org/10.1016/j.egypro.2009.02.109

Curti E (1999) Coprecipitation of radionuclides with calcite: estimation of partition coefficients based on a review of laboratory investigations and geochemical data. Appl Geochem. 14: 433-445. http://dx.doi.org/10.1016/S0883-2927(98)00065-1

Cuthbert MO, Riley MS, Handley-Sidhu S, Renshaw JC, Tobler DJ, Phoenix VR, Mackay R (2012) Controls on the rate of ureolysis 
and the morphology of carbonate precipitated by S. Pasteurii biofilms and limits due to bacterial encapsulation. Ecol Eng. 41:32-40. http://dx.doi.org/10.1016/j.ecoleng.2012.01.008

De Muynck W, Debrouwer D, De Belie N, Verstraete W (2008) Bacterial carbonate precipitation improves the durability of cementitious materials. Cement Concrete Res. 38:1005-1014. http://dx.doi.org/10.1016/j.cemconres.2008.03.005

De Muynck W, De Belie N, Verstraete W (2010) Microbial carbonate precipitation in construction materials: a review. Ecol Eng 36:118-136. http://dx.doi.org/10.1016/j.ecoleng.2009.02.006

Druckenmiller ML, Maroto-Valer MM, Hill M (2006) Investigation of carbon sequestration via induced calcite formation in natural gas well brine. Energ Fuel 20:172-179

Dupraz S, Parmentier M, Menez B, Guyot F (2009) Experimental and numerical modeling of bacterially induced $\mathrm{pH}$ increase and calcite precipitation in saline aquifers. Chem Geol. 265:44-53. http://dx.doi.org/10.1016/j.chemgeo.2009.05.003

Ferris FG, Stehmeier LG, Kantzas A, Mourits FM (1996) Bacteriogenic mineral plugging. J Can Petrol Technol 35:56-61

Ferris FG, Phoenix V, Fujita Y, Smith RW (2004) Kinetics of calcite precipitation induced by ureolytic bacteria at 10 to 20 degrees $C$ in artificial groundwater. Geochim Cosmochim Acta. 68:1701-1710. http://dx.doi.org/10.1016/S0016-7037(03)00503-9

Fridjonsson E, Seymour JD, Schultz LN, Gerlach R, Cunningham AB, Codd SL (2011) NMR measurement of hydrodynamic dispersion in porous media subject to biofilm mediated precipitation reactions. J Contam Hydrol. 120-121:79-88. http://dx. doi.org/10.1016/j.jconhyd.2010.07.009

Fujita Y, Redden GD, Ingram JC, Cortez MM, Ferris FG, Smith RW (2004) Strontium incorporation into calcite generated by bacterial ureolysis. Geochim Cosmochim Acta. 68:3261-3270. http://dx.doi.org/10.1016/j.gca.2003.12.018

Fujita Y, Taylor JL, Gresham TLT, Delwiche ME, Colwell FS, Mcling TL, Petzke LM, Smith RW (2008) Stimulation of microbial urea hydrolysis in groundwater to enhance calcite precipitation. Environ Sci Technol 42:3025-3032. doi:10.1021/ es702643g

Fujita Y, Taylor JL, Wendt LM, Reed DW, Smith RW (2010) Evaluating the Potential of Native Ureolytic Microbes To Remediate a (90)Sr Contaminated Environment. Environ Sci Technol. 44:7652-7658. doi:10.1021/es101752p

Ghosh S, Biswas M, Chattopadhyay BD, Mandal S (2009) Microbial activity on the microstructure of bacteria modified mortar. Cement Concrete Comp. 31:93-98. http://dx.doi.org/10.1016/ j.cemconcomp.2009.01.001

Gianfreda L, Rao MA, Violante A (1992) Adsorption, activity and kinetic-properties of urease on montmorillonite, aluminum hydroxide and $\mathrm{Al}(\mathrm{OH}) \mathrm{x}$-montmorillonite complexes. Soil Biol Biochem. 24:51-58. http://dx.doi.org/10.1016/0038-0717(92)90241-O

Hammes F, Seka A, Van Hege K, Van De Wiele T, Vanderdeelen J, Siciliano SD, Verstraete W (2003) Calcium removal from industrial wastewater by bio-catalytic $\mathrm{CaCO}_{3}$ precipitation. J Chem Technol Biot 78:670-677. doi:10.1002/jctb.840

Krajewska B (2009a) Ureases I. Functional, catalytic and kinetic properties: A review. J Mol Catal B-Enzym. 59:9-21. http://dx. doi.org/10.1016/j.molcatb.2009.01.003

Krajewska B (2009b) Ureases. II. Properties and their customizing by enzyme immobilizations: A review. J Mol Catal B-Enzym. 59:22-40. http://dx.doi.org/10.1016/j.molcatb.2009.01.004
Marzadori C, Miletti S, Gessa C, Ciurli S (1998) Immobilization of jack bean urease on hydroxyapatite: Urease immobilization in alkaline soils. Soil Biol Biochem. 30:1485-1490. http://dx. doi.org/10.1016/S0038-0717(98)00051-0

Mitchell AC, Ferris FG (2006) The influence of Bacillus pasteurii on the nucleation and growth of calcium carbonate. Geomicrobiol J 23:213-226. doi:10.1080/01490450600724233

Mitchell AC, Dideriksen K, Spangler LH, Cunningham AB, Gerlach R (2010) Microbially enhanced carbon capture and storage by mineral-trapping and solubility-trapping. Environ Sci Technol 44:5270-5276. doi:10.1021/es903270w

Nemati M, Voordouw G (2003) Modification of porous media permeability, using calcium carbonate produced enzymatically in situ. Enzyme Microb Tech. 33:635-642. http://dx.doi.org/10. 1016/S0141-0229(03)00191-1

Nemati M, Greene EA, Voordouw G (2005) Permeability profile modification using bacterially formed calcium carbonate: Comparison with enzymic option. Process Biochem. 40:925-933. http://dx.doi.org/10.1016/j.procbio.2004.02.019

Ramachandran SK, Ramakrishnan V, Bang SS (2001) Remediation of Concrete using Microorganisms. ACI Materials J. 98:3-9. http:// scholar.google.co.uk/scholar_url?hl=en\&q=http://sphinx.murdoch. edu.au/units/extern/BIO301/teach/download/Chemostat/B\%2520 pasteuri\%2520literature $\% 2520$ examples/Concrete $\% 2520$ remedia tion\%2520with\%2520B.\%2520pasteurii.pdf\&sa=X\&scisig=AAG Bfm0br1C_y3W0VhCFRTbHJJx0izJqbw\&oi=scholarr\&ei=IgFzTGQB-nV0QXEyIQQ\&ved=0CCQQgAMoADAA

Stevenson P, Mantle MD, Sederman AJ, Gladden LF (2007) Quantitative Measurements of Liquid Holdup and Drainage in Foam Using NMRI. AIChE J 53:290-296

Stocks-Fischer S, Galinat JK, Bang SS (1999) Microbiological precipitation of $\mathrm{CaCO}_{3}$. Soil Biol Biochem. 31:1563-1571. http://dx.doi.org/10.1016/S0038-0717(99)00082-6

Tobler DJ, Cuthbert MO, Greswell RB, Riley MS, Renshaw JC, Handley-Sidhu S, Phoenix VR (2011) Comparison of rates of ureolysis between Sporosarcina pasteurii and an indigenous groundwater community under conditions required to precipitate large volumes of calcite. Geochim Cosmochim Acta. 75:32903301. http://dx.doi.org/10.1016/j.gca.2011.03.023

Tobler DJ, Maclachlan E, Phoenix VR (2012) Microbially mediated plugging of porous media and the impact of differing injection strategies. Ecol Eng. 42:270-278. http://dx.doi.org/10.1016/j. ecoleng.2012.02.027

Van Paassen LA (2009) Biogrout ground improvement by microbially induced carbonate precipitation, Ph.D thesis, Delft University of Technology, The Netherlands

Warren LA, Maurice PA, Parmer N, Ferris FG (2001) Microbially mediated calcium carbonate precipitation: implications for interpreting calcite precipitation and for solid phase capture of inorganic contaminants. Geomicrobiol J 18:93-115. doi: $10.1080 / 01490450151079833$

Whiffin VS (2004) Microbial CaCO3 precipitation for the production of biocement, $\mathrm{PhD}$ thesis, Murdoch University, Western Australia. http://www.google.co.uk/url?sa=t\&rct=j\&q=\&esrc=s\&frm $=1 \&$ source=web\&cd $=1 \&$ ved $=0$ CCQQFjAA\&url=http $\% 3 \mathrm{~A} \% 2 \mathrm{~F} \%$ 2Fresearchrepository.murdoch.edu.au $\% 2 \mathrm{~F} 399 \% 2 \mathrm{~F} 2 \% 2 \mathrm{~F} 02$ Whole.pdf\&ei=VAhzT_enDeOm0QWe35jsDw\&usg=AFQjCNF 97-rpP_09kKyqILpyDE2fHAEp0g\&sig2=XWkwMNpibYDKD MIJNIJm1A 
Whiffin VA, Van Paassen LA, Harkes MP (2007) Microbial carbonate precipitation as a soil improvement technique. Geomicrob J. 24:417-423. doi:10.1080/01490450701436505

White CM, Strazisar BR, Granite EJ, Hoffman JS, Pennline HW (2003) Separation and capture of $\mathrm{CO}_{2}$ from large stationary sources and sequestration in geological formations-coalbeds and deep saline aquifers. J Air Waste Manage Assoc. 53:645-715. http://www.ncbi.nlm.nih.gov/pubmed/12828330 